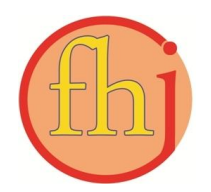

Faletehan Health Journal, 5 (2) (2018) 55-60

https://journal.Ippm-stikesfa.ac.id

ISSN 2088-673X| e-ISSN 2597-8667

\title{
Perilaku Pemeliharaan Kesehatan Gigi dan Mulut pada Anak Autisme
}

\author{
Ervon Veriza ${ }^{1 *}$, Hendry Boy ${ }^{1}$ \\ 1Prodi DIV Jurusan Keperawatan Gigi Poltekkes Kemenkes RI Jambi, Indonesia \\ *Corresponding Author: ervonveriza@gmail.com
}

\begin{abstract}
Abstrak
Salah satu anak berkebutuhan khusus adalah anak-anak autis, merupakan salah satu sumber daya bangsa Indonesia yang kualitasnya harus ditingkatkan agar dapat berperan, tidak hanya sebagai obyek pembangunan tetapi juga sebagai subyek pembangunan. Anak berkebutuhan khusus memerlukan pelayanan yang bersifat khusus, seperti pelayanan medik, pendidikan khusus maupun latihan-latihan tertentu yang bertujuan untuk mengurangi keterbatasan dan ketergantungan akibat kelainan yang diderita, serta menumbuhkan kemandirian hidup dalam bermasyarakat. Tujuan penelitian ini adalah untuk mendapatkan informasi mendalam tentang perilaku pemeliharaan kesehatan gigi dan mulut di Sekolah Khusus Harapan Mulia Jambi Selatan. Penelitian menggunakan pendekatan kualitatif menggunakan indepth interview dengan triangulasi sumber yaitu orang tua/pengasuh, guru-guru dan psikolog yang membina di SLB Harapan Mulia. Hasil penelitian menunjukkan bahwa bahwa perilaku pemeliharaan kesehatan gigi dan mulut pada anak autis tergantung pada ibu atau pengasuhnya. Berdasarkan faktor pendukung dalam perilaku pemeliharaan kesehatan gigi yaitu ketersediaan sarana pelayanan kesehatan gigi dan mulut masih kurang. Sebagian besar informan mencari pelayanan kesehatan gigi/dokter gigi yang sudah dikenal atau dipercaya, tidak ramai, tidak terlalu lama antri/menunggu. Faktor pendorong/penguat perilaku pemeliharaan kesehatan gigi dan mulut pada anak autis di rumah adalah ibunya atau pengasuhnya, sedangkan di sekolah adalah guru pendampingnya.
\end{abstract}

Kata Kunci: Autisme, Kesehatan gigi dan mulut, Perilaku pemeliharaan

\begin{abstract}
Children with special needs is one of Indonesia's human resources whose quality must be improved in order to play a role, not only as the object of development but also as the subject of development. Children with special needs need to be identified and identified from the group of children in general, because they require special services, such as medical services, special education and specific exercises aimed at reducing the limitations and dependence of the disorder suffered, and foster self-reliance in the community. The purpose of this study was to obtain in-depth information about dental and oral health care behavior in children with autism in Harapan Mulia Special School in South Jambi. Qualitative research method using indepth interview with triangulation of source that is parent or caregiver, teachers and psychologist who build in SLB Harapan Mulia. The results show that the behavior of maintaining good oral hygiene in children with autism depending on the mother or caregiver. Supporting factors include the availability of dental and oral health facilities are still lacking, most of the informants looking for dental services or dentists who are known or trusted, not crowded so that children can also be comfortable and children not too long waiting. Reinforcing factor the behavior of maintaining good oral hygiene in children with autism at home is his mother or caregiver, while in school is a teacher companion.
\end{abstract}

Keywords: Autism, Health behaviour , M aintenance of oral and dental health. 


\section{Pendahuluan}

Data Riset Kesehatan Dasar (RISKESDAS, 2013) menyebutkan bahwa angka permasalahan gigi dan mulut di Indonesia mencapai $25,9 \%$ atau mengalami peningkatan 2,5\% dari Riskedas tahun 2007. Hal ini disebabkan banyak faktor diantaranya adalah perilaku pemeliharaan kesehatan gigi dan mulut yang masih belum konsisten/menetap sebagai perilaku yang langgeng. Perilaku pemeliharaan kesehatan gigi dan mulut diperlukan oleh semua elemen masyarakat, mulai dari anak-anak sampai lansia, baik manusia dalam kondisi normal maupun yang berkebutuhan khusus. Menurut WHO jumlah anak berkebutuhan khusus di Indonesia sekitar 7-10 \% dari total jumlah anak. Anak Berkebutuhan Khusus ( ABK ) yaitu anak dengan keterbatasan fisik dan mental yang memiliki keterbatasan kondisi fisik perkembangan, tingkah laku atau emosi.

Masalah sosial pada anak berkebutuhan khusus mempengaruhi kebutuhan pendidikan anakanak tersebut diantaranya adalah ABK memiliki pengetahuan yang masih kurang khususnya pengetahuan di bidang kesehatan gigi dan mulut. Pengetahuan tentang cara memelihara kesehatan gigi yang rendah mendukung tingginya angka karies pada anak berkebutuhan khusus. Hal ini berarti bahwa anak-anak berkebutuhan khusus memerlukan jenis pelayanan kesehatan lebih dari yang dibutuhkan oleh anak normal secara umum. (Tugalow dkk, 2015). Terkait dengan permasalahan gigi dan mulut pada anak berkebutuhan khusus, Tugalow dkk, (2015) juga menyatakan bahwa status karies gigi pada anak berkebutuhan khusus di SLB YPAC Manado dengan Indeks DMF-T sebesar 4,4 termasuk kategori sedang. Kesehatan gigi dan mulut pada anak berkebutuhan khusus lebih rendah dibandingkan dengan anak normal, hal tersebut dikarenakan kesulitan yang dialami oleh anak berkebutuhan khusus yaitu rendahnya kemampuan motorik serta kognitifnya (Supriyani, Ririn; Anggraini, 2014).

Dalam jurnal" Tooth brushing intervention Programe Among Children with mental Handicap" cit Tugalow,2015 menyebutkan bahwa kebersihan gigi dan mulut serta penyakit periodontal merupakan masalah terbesar yang dialami penyandang cacat. Anak berkebutuhan khusus memiliki tingkat kesehatan dan kebersihan mulut yang lebih rendah jika dibandingkan dengan anak normal. Anak berkebutuhan khusus tidak bisa menjalankan aktifitas kehidupan sehari-hari secara normal sehingga perlu bantuan orang lain disekitarnya. Hal ini sejalan dengan hasil penelitian Putri (2014), yang menyatakan bahwa tingkat kebersihan gigi dan mulut pada siswa-siswi SLB-A bertambah baik sesudah mendapat bimbingan penyikatan gigi disertai pembimbingan secara lisan pada setiap kunjungan pendidikan. Menurut penelitian Indahwati, Vivie dkk, anak berkebutuhan khusus merupakan anak yang memiliki keterbatasan mental, fisik dan emosi yang berbeda dengan anak normal, sehingga mereka memerlukan bantuan dalam menjaga kebersihan gigi dan mulutnya (Vivie, 2015).

Menurut teori Lawrence Green, kesehatan individu / masyarakat dipengaruhi oleh dua faktor pokok yaitu faktor perilaku dan faktor diluar perilaku (non-perilaku). Faktor perilaku ditentukan oleh 3 faktor yaitu faktor predisposisi, faktor pendukung dan faktor pendorong. Faktor pendukung bagi anak berkebutuhan khusus diantaranya yaitu penyediaan pelayanan kesehatan. Ketersediaan pelayanan kesehatan bagi anak berkebutuhan khusus harus sesuai dengan peraturan Kemenkes 2010 yang menyebutkan bahwa pelayanan kesehatan bagi seluruh masyarakat tanpa diskriminasi (non-diskriminasi), begitu pula dengan faktor pendorong pelayanan kesehatan seperti petugas kesehatan, orang tua, guru atau pengasuhnya juga memegang peran penting bagi perubahan perilaku bagi anak-anak berkebutuhan khusus.

Sekolah Khusus Harapan Mulia adalah sekolah swasta yang mendidik anak-anak berkebutuhan khusus terutama anak autisme. Pada sekolah ini terdapat psikologi klinik khusus yang ikut membantu mendidik perkembangan anak-anak di sekolah tersebut. Sekolah tersebut memiliki siswa sebanyak 130 orang. Pada survei awal pemeriksaan gigi pada anak autisme di Sekolah Khusus Harapan Mulia, dari 5 anak yang diperiksa ditemukan 3 orang anak mengalami karies, yang kemungkinan disebabkan karena pemeliharaan kesehatan gigi dan mulut yang masih kurang.

Tujuan penelitian ini adalah untuk mengetahui secara mendalam faktor pendukung (ketersediaan sumber daya kesehatan) dan faktor pendorong (sikap dan perilaku orang tua/pendamping) dalam pemeliharaan kesehatan gigi dan mulut pada anak autis di Sekolah Khusus Harapan Mulia. 
Faletehan Health Journal, 5 (2) (2018) 55-60 https://journal.Ippm-stikesfa.ac.id ISSN 2088-673X | e-ISSN 2597-8667

\section{Metode Penelitian}

Penelitian ini menggunakan metode kualitatif dengan wawancara mendalam pada orang tua murid, guru-guru, kepala sekolah dan pemilik Yayasan. Triangulasi sumber pada penelitian ini dilakukan kepada informan yaitu orang tua anak berkebutuhan khusus dan pengasuhnya, sedangkan informan kunci adalah guru, dan psikolog yang membina ABK di SLB Harapan Mulia. Informan yang bersedia diwawancarai sebanyak 14 orang ibu yang mempunyai anak autis. Wawancara dilakukan oleh 2 orang peneliti dan dibantu dengan pembantu lapangan untuk mencatat dan merekam hasil wawancara. Informan kunci diwawancarai setelah peneliti selesai mewawancarai semua informan.

\section{Hasil dan Pembahasan}

\section{Faktor pemungkin/pendukung (enabling factor)}

Enabling factor yaitu tersedianya pelayanan kesehatan dan kemudahan untuk mencapainya. Pada hasil wawancara mendalam untuk mengetahui dimana anak autis memeriksakan giginya atau berobat jika sakit gigi menunjukkan bahwa hampir semua anak autis jarang melakukan pemeriksaan gigi ke pelayanan kesehatan atau dokter gigi karena sebagian besar anak tidak ada keluhan tentang kesehatan gigi dan mulut. Jika ada keluhan, ibu biasanya pergi ke dokter gigi yang tidak ramai karena takut anaknya lama menunggu dan mengganggu pasien lainnya. Hal ini dapat dilihat dari cuplikan hasil wawancara mendalam dengan ibu dari anak autis :

\section{"Pergi ke dokter gigi yang tidak ramai pasiennya supaya anak tidak lama menunggu antri dan anak tidak mengganggu pasien lain”}

Hasil wawancara mendalam tentang apakah mudah mendapatkan pelayanan kesehatan gigi dan mulut atau dokter gigi yang mau merawat anak autis? Sebagian besar orang tua tidak memberitahukan ke dokter giginya bahwa anaknya autis karena malu, ada seorang ibu yang mengatakan kepada petugas kesehatan bahwa anaknya autis, lalu tidak menerima anaknya untuk berobat di pelayanan kesehatan lagi karena anak ketakutan ketika duduk di kursi gigi dengan lampu dan suara mesin giginya membuat anak berteriakteriak. seperti terlihat dalam cuplikan sebagai berikut :
"Dulu pernah umur 7 tahun pada saat gigi depannya berlubang dibawa ke puskesmas, pada saat dibawa ke puskesmas untuk membersihkan giginya yang berlubang tetapi ditolak orang puskesmas karena anaknya berkebutuhan khusus"

Hasil wawancara mendalam tentang apakah jauh tempat pelayanan kesehatan/ dokter gigi dari tempat tinggal ? sebagian besar anak autis dibawa ke pelayanan kesehatan/dokter gigi yang sudah kenal dengan keluarga walaupun jauh. Hal ini dapat dilihat dari hasil cuplikan wawancara mendalam pada beberapa ibu anak autis sebagai berikut:

\section{"agak jauh dari tempat tinggal, karena pelayanan kesehatan yang dikunjungi memang udah biasa karena percaya"}

Faktor pemungkin mencakup berbagai keterampilan dan sumber daya yang perlu untuk melakukan perilaku kesehatan. Sumber daya meliputi fasilitas pelayanan kesehatan, dan keterjangkauan/kemudahan memperoleh sumber daya/sarana tersebut seperti biaya, jarak, ketersediaan transportasi, jam buka dan keterampilan petugas kesehatan. Dari hasil wawancara dengan informan hampir semua anak autis jarang melakukan pemeriksaan gigi ke pelayanan kesehatan atau dokter gigi karena sebagian besar anak tidak ada keluhan tentang kesehatan gigi dan mulut, jika ada keluhan ibu biasanya pergi ke dokter gigi yang tidak ramai karena takut anaknya lama menunggu dan mengganggu pasien lainnya. Beberapa informan mengatakan anaknya agak sulit untuk dipegang/diperiksa oleh orang lain apalagi anak belum mengenalnya, maka anak tidak mau dilakukan pemeriksaan, biasanya anak autis harus didampingi oleh ibunya atau orang terdekatnya seperti guru atau terapisnya. Hal ini sesuai dengan hasil penelitian Sengkey, dkk (2015) Anak -anak autis biasanya kurang merasakan kontak sosial dan mereka cenderung menyendiri dan menghindari kontak dengan orang lain (Sengkey, dkk, 2015).

Fasilitas pelayanan kesehatan gigi bagi anak autis belum tersedia dengan kemudahan memperolehnya dan keterampilan petugas kesehatan gigi dalam memberikan pelayanan kesehatan gigi dan mulut pada anak berkebutuhan khusus. Salah seorang informan mengatakan 
bahwa anaknya yang autis pernah berobat ke puskesmas lalu disaat anak duduk di kursi gigi dan mesin dihidupkan anaknya berteriak ketakutan lalu petugas kesehatan tidak mampu menanganinya dan menolak untuk dilakukan perawatan. Hal ini sama dengan yang diteliti Megawati (2013) kesulitan yang dialami para tenaga kesehatan gigi pada saat menangani anak berkebutuhan khusus, kendala yang dihadapi di ruang praktek, karena pada umumnya penyandang autis sulit beradaptasi pada lingkungan baru. Klinik perawatan gigi dianggap sebagai tempat baru sehingga mereka sulit beradaptasi, sehingga menyebabkan mereka ketakutan atau menunjukkan reaksi lainnya saat berada di ruang perawatan gigi. Oleh karena itu menurut Megawati (2013) anak autis membutuhkan penanganan komprehensif yang melibatkan berbagai ahli di sejumlah bidang yaitu pakar kedokteran, pakar kedokteran gigi, psikolog serta pendidik. Teknik perawatan pada anak autis adalah TSD (Tell-Show-Do) yaitu dengan kunjungan yang berulang dan pengenalan terhadap peralatan kedokteran gigi, dapat membuat anak familiar terhadap lingkungan ruang praktik, hindari tindakan yang dapat menimbulkan rasa sakit pada penderita, menghindari suara bor atau handpiece karena anak autis sensitivitas tinggi terhadap suara, cahaya, bau dan warna menghendaki perhatian yang khusus untuk mengurangi ataupun menghindarkan stimulasi sensoris.

\section{Faktor pendorong/penguat (reinforcing factor)}

Faktor penguat adalah faktor yang menentukan apakah tindakan kesehatan memperoleh dukungan atau tidak. Sebagian besar informan yang diwawancarai mengatakan kebersihan gigi dan mulut anak dijaga oleh ibu/pengasuhnya yaitu menyuruh dan mengingatkan untuk menyikat gigi setiap hari. Hal ini dapat dilihat dari beberapa cuplikan hasil wawancara dengan ibu anak autis sebagai berikut:

“ anak sudah bisa menyikat gigi sendiri sejak masuk sekolah harapan mulia, tetapi Suster Dewi selalu membantu membersihkan gigi agar bersih karena michael menyikat gigi hanya yang mau dia sikat saja"(102)

“ anak menyikat gigi sendiri tetapi disikat ulang dengan ibu karena kurang bersih"

" bisa menyikat gigi sendiri, tetapi caranya asal-asalan maka ibu menyikat ulang gigi anak dan sesuai keinginan anak mana yang dulu disikat" (103)

" bisa melakukan sikat gigi sendiri tetapi harus dibimbing karena berkumur belum bisa (sikat gigi belum sempurna) ibu yang selalu membantu membersihkan gigi anaknya" (104)

Sebagian besar anak autis mau diperiksa giginya bila didampingi oleh orang terdekatnya seperti ibunya, suster atau guru pendampingnya di Sekolah Harapan Mulia. Hal ini terlihat pada cuplikan hasil wawancara mendalam pada ibu anak autis sebagai berikut:

“ anak kalau mau diperiksa dokter gigi harus membawa guru pendampingnya, namanya bu Intan karena michael lebih mendengarkan gurunya" (101)

" anak mau diperiksa kalau pergi bersama ibu dan bapaknya, anak mau diperiksa bila tidak dipaksa" (104)

" bersama ibu karena anak lebih dekat dengan ibu, anak mau dilakukan pemeriksaan gigi bila disuruh dan ditemani dengan ibunya" (106)

Faktor penguat adalah faktor yang menentukan apakah tindakan kesehatan gigi anak autis memperoleh dukungan atau tidak. Sumber penguat pada anak autis adalah orang tua terutama ibu/pengasuhnya, guru dan psikolog nya. Hampir semua informan mengatakan bahwa anaknya belum sempurna dalam menjaga kebersihan gigi dan mulutnya, harus selalu di dampingi oleh ibu atau pengasuhnya dalam membersihkan giginya setiap hari. Menurut Anisyah, Ika (2014) peranan orang tua sangat penting baik di rumah maupun di rumah sakit, ketika perawatan gigi di rumah, orang tua bisa mengajarkan anak dengan memberikan contoh di depan cermin yang besar agar anak bisa langsung melihat dengan jelas apa yang dilakukan orang tuanya, setelah itu bimbinglah anak melakukan apa yang dilakukan orang tuanya mulai dari memegang sikat gigi, menggunakan pasta gigi dan gerakan menyikat giginya.oleh karena itu sikap dan praktik orang tua terutama ibu sangatlah berperan dalam mempengaruhi status kesehatan gigi anak-anak mereka (Green, terjemah Mamdy, dkk, 2007).

Penguatan lain dalam meningkatkan perilaku, seperti dalam buku Kent and Blinkhorn (2005) penguatan (reinforcement) diberikan kepada anak yang menurut dan dapat bekerjasama dalam perawatan gigi seperti memberi pujian atau hadiah 
Faletehan Health Journal, 5 (2) (2018) 55-60 https://journal.Ippm-stikesfa.ac.id ISSN 2088-673X | e-ISSN 2597-8667

kecil berupa gambar tempel atau makanan yang disukainya. Hal ini sejalan dengan apa yang dikatakan informan kunci (psikolog) bahwa untuk kepatuhan anak autis caranya dengan pemberian reward setiap yang dilakukan anak sesuai dengan perintah, rewardnya pada anak-anak dengan makanan kalau sudah besar bisa dengan pujian.

Perilaku pemeliharaan kesehatan gigi dan mulut pada anak berkebutuhan khusus (autisme)

Perilaku pemeliharaan kesehatan gigi dan mulut adalah tindakan untuk memelihara kesehatan gigi dan mulut yaitu berapa kali menyikat gigi sehari, kapan waktunya, dan mengkonsumsi makanan yang dapat menyehatkan gigi dan mulut, mengurangi makanan yang merusak gigi. Dari hasil wawancara mendalam sebagian besar anak menyikat gigi setiap hari ada yang 2 kali sehari, ada yang 3 kali sehari dan ada juga yang hanya 1 kali sehari, dengan waktu yang bervariasi terlihat dari hasil cuplikan wawancara sebagai berikut:

" menyikat gigi 3 x sehari, pagi waktu mandi, siang setelah makan disekolah dna malam sebelum tidur" (101)

“ menyikat gigi 3 x sehari yaitu pagi setelah bangun tidur, pagi setelah sarapan dan malam sebelum tidur" (103)

" $1 x$ sehari pagi saja karena jam tidur anak terlalu sore bangunnya, dan waktu mandi terburu-buru jadi menyikat gigi kadang tidak terlaksana” (104)

Untuk konsumsi makanan yang menyehatkan dan merusak gigi, hampir semua informan mengatakan anak mereka diet, yaitu tidak boleh makan yang manis-manis, susu,gandum dan penyedap rasa. Sedangkan anak-anak setiap hari diberi buah-buahan yang dianjurkan agar terapinya berjalan dengan baik. Hal ini bisa terlihat dari hasil cuplikan wawancara mendalam sebagai berikut:

" anak diet makanan yang dilarang untuk mereka seperti makanan yang manis-manis, chiki atau yang ada penyedap ras, jadi makanan dibuat sendiri di rumah, dan makan buah-buahan setiap hari" (101)

"Makanan dimasak sendiri, makan $4 x$ sehari, makanan manis adalah pantangan anak, anak makan buah rutin tiap hari seperti semangka, pir, melon, buah naga dan lain lain" (102)

" Makanan dibuat sendiri oleh ibu, makan $3 x$ sehari pagi, siang dan sore. Pantangannya yaitu susu, keju, gandum, jagung, kalau salah makan anak akan langsung terjadi perubahan jadi eror, marah-marah, ketawa-ketawa sendiri, hentak-hentak kaki" (103)

Hal tersebut sesuai dengan apa yang dikatakan oleh informan kunci yaitu gurunya, kepala sekolahnya dan psikolog. Terlihat dari hasil cuplikan wawancara sebagai berikut:

“ Disekolah anak-anak autis yang baru masuk maka dibantu dalam menyikat giginya tetapi setelah beberapa bulan anak akan mandiri, maka anak menyikat gigi sendiri tetapi tetap harus diingatkan, pada anak autis teratur kegiatannya karena sudah rutinitas dan anak autis sangat konsisten dan terkonsep kepatuhan anak autis memiliki pantangan dalam makanan yang dikonsumsi" (guru neni)

" Metode terapi anak autis menggunakan metode ABA yaitu applied behavior analyze yaitu bagaimana meminimalkan perilaku negatif dan memaksimalkan perilaku positif dengan metode reward dan efek jera sehingga anak menjadi patuh untuk kemudian baru bisa memasukkan program apa pada anak. Anak autis pantangannya yaitu diet CF (Casein Free), GF (Glutein Free) SF (Sugar Free) dan elektronik" (kepala sekolah)

" Menggunakan metode behavior dari Lovaz yaitu ABA (applied behavior analyze) yaitu membantu anak lebih rileks, lebih fokus dan lebih baik kontak matanya.” (psikolog)

Perilaku pemeliharaan kesehatan gigi dan mulut adalah tindakan untuk memelihara kesehatan gigi dan mulut yaitu berapa kali menyikat gigi sehari, kapan waktunya, dan mengkonsumsi makanan yang dapat menyehatkan gigi dan mulut, mengurangi makanan yang merusak gigi, serta pemeriksaan gigi rutin. Dari hasil wawancara pada informan sebagian besar anak autis menyikat gigi frekuensinya sudah tepat yaitu minimal 2 kali sehari tetapi ada yang lebih, hanya saja waktunya menyikat gigi masih banyak yang kurang tepat yaitu pada saat mandi pagi dan mandi sore. Hal tersebut dalam analisis tingkah laku bahwa menyikat gigi sering dikaitkan dengan mandi, bahwa setiap orang mandi pasti akan menyikat gigi. Pemacu tingkah laku tergantung pada dampak dari tingkah laku tersebut, contohnya bila 
seseorang melakukan suatu tindakan dan pengaruhnya dirasakan menguntungkan orang tersebut pasti akan mengulangi tindakan tersebut. (Kent and Blinkhorn, 2005)

Pada konsumsi makanan yang menyehatkan gigi dan mengurangi makanan yang merusak gigi dari hasil wawancara didapatkan informasi bahwa semua informan mengatakan anaknya selalu makan buah-buahan yang dianjurkan dokter atau terapisnya, sedangkan makanan yang merusak gigi seperti makanan yang manis dan melekat tidak dikonsumsi oleh anak autis karena makanan tersebut adalah makanan pantangan/makanan yang tidak boleh dikonsumsi anak autis. Karena pantangan makanan tersebut maka sebagian besar anak autis yang di teliti di sekolah khusus harapan mulia giginya bagus tanpa karies, karena salah satu faktor terjadi karies yaitu makanan terutama karbohidrat yang manis dan melekat, makanan tersebut tidak dikonsumsi oleh anak autis.

Pada pemeriksaan rutin gigi anak autis ke pelayanan kesehatan atau dokter gigi, semua informan mengatakan belum pernah memeriksakan gigi anaknya kecuali ada keluhan, menurut Anisyah (2014) kebanyakan orang tua tidak mengetahui apa yang sedang terjadi pada gigi anak berkebutuhan khusus karena anak tersebut tidak mengatakan kepada orang tuanya jika terjadi gigi yang goyang, ada gigi yang tumbuh dan lainnya kecuali jika orang tuanya yang memeriksanya. Oleh karena itu peranan orang tua dalam pemeliharaan kesehatan gigi dan mulut sangat besar mengingat keterbatasan dari anak berkebutuhan khusus tersebut.

\section{Simpulan dan Saran}

Perilaku pemeliharaan kesehatan gigi dan mulut pada anak autis tergantung dari ibu atau pengasuhnya ketika berada di rumah sedangkan di sekolah perilaku pemeliharaan kesehatan gigi dibantu oleh guru pendamping. Keluarga mencari sarana pelayanan kesehatan gigi dan mulut ke klinik gigi/dokter gigi yang sudah dikenal, dipercaya dan tidak ramai agar anak tidak terlalu lama antri/menunggu.

\section{Daftar Pustaka}

Anisyah, I. (2014). Perawatan gigi anak" Spesial” Media clipping.

Green, L et. al (2007)" Perencanaan pendidikan kesehatan sebuah pendekatan diagnostik" diterjemahkan oleh Mamdy, Zulazmy ; Tafal, Zarfiel ; Kresno, Sudarti. Departemen Pendidikan dan Kebudayaan RI. Jakarta.

Putri, M. H. (2014)" Pengaruh pendidikan penyikatan gigi dengan Menggunakan model rahang dibandingkan dengan metode pendampingan terhadap tingkat kebersihan gigi dan mulut siswa-siswi tunanetra SLB-A Bandung" Majalah Kedokteran Bandung, volume 46 no. 3 September 2014.

Kemenkes RI. (2010). Pedoman pelayanan kesehatan anak di sekolah luar biasa (SLB) bagi petugas kesehatan” Jakarta : Dirjen Bina kesmas Kemenkes, 2010

Kemenkes RI. ( 2013). Riset kesehatan dasar tahun 2013.

Kent,G.G., \& Blinkhorn, A.S. (2005). Pengelolaan tingkah laku pasien pada praktik dokter gigi. Jakarta : EGC

Kresno, S. dkk (2000). Aplikasi metode kualitatif dalam penelitian kesehatan. Depok.

Mahfoedz \& Zein (2005). Pemeliharaan kesehatan gigi dan mulut pada balita dan ibu hamil.

Megawati, J. (2013). Perawatan gigi anak autis. http ://joglosemar.co

Notoatmodjo, S. (2010). Promosi kesehatan : teori dan aplikasi. Edisi revisi. Yogyakarta : Rineka Cipta.

Sengkey, M. dkk. (2015). Status kebersihan gigi dan mulut pada anak autis di kota Manado. Jurnal E-Gigi vol. 3 Nomor 2, Juli Desember 2015

Tugalow, dkk. (2016). Gambaran status karies pada anak berkebutuhan khusus di SLB YPAC Manado. Jurnal E-Gigi Vol. 3, Nomor 2 Juli-Desember 2015. 